\title{
GENOTOXICITY OF FORMALDEHYDE IN PERIPHERAL BLOOD LYMPHOCYTES AMONG PATHOLOGY LABORATORY WORKERS
}

\author{
By \\ ${ }^{1}$ Zayet HH, 1Lotfy BM, ${ }^{2}$ Sabry DA, ${ }^{3}$ Mohamed OE, ${ }^{1}$ Said RM \\ ${ }^{1}$ Department of Occupational and Environmental Medicine, ${ }^{2}$ Department of Medical Biochemistry and \\ Molecular Biology, Faculty of Medicine, Cairo University. ${ }^{3}$ Human Cytogenetics, National Research Center.
}

\begin{abstract}
Introduction: Formaldehyde (FA) is a chemical, traditionally used in pathology and anatomy laboratories as a tissue preservative. Many studies clearly indicated that FA can induce genotoxic effects in peripheral blood lymphocytes. Aim of work: to evaluate the genotoxic effects of formaldehyde among medical and paramedical personnel in The Histopathology Laboratory. Materials and Methods: The study was conducted in histopathology laboratory including 30 workers occupationally exposed to formaldehyde and 29 persons from other lab in kasr Al Aini hospital matching the exposed group for age, sex and socioeconomic status with no history of occupational exposure to formaldehyde. A questionnaire was done including inquiries about age, sex, occupational history and special habits. All participants were subjected to the following laboratory investigations: measuring DNA protein crosslink (DPC), sister chromatid exchange (SCE) and micronucleus $(\mathrm{Mn})$ frequency in peripheral blood lymphocytes. Environmental monitoring of the work place was done to measure the level of FA at different place in the pathology lab. Results: This study showed statistically significant increase of DPC with significant increase in sister chromatid exchange (SCE) and micronucleus $\mathrm{MN}$ in peripheral blood lymphocytes. Conclusion: The studied group was exposed to formaldehyde level above the exposure limits recommended by NIOSH, ACGIH and OSHA with adverse health effects in the form of increase in DPC, SCE and $\mathrm{Mn}$ as genotoxicity biomarkers. These genotoxicity biomarkers are considered to play an important role in the carcinogenesis of FA.
\end{abstract}

Key words: Formaldehyde, Environmental monitoring, Sister chromatide exchange, Micronucleus, DNA protein crosslink. 


\section{Introduction}

Formaldehyde (FA) is a highproduction-volume chemical with a wide array of uses. The highest level of human exposure to FA occurs in occupational settings. Occupational exposure involves not only individuals employed in the direct manufacture of FA and products containing this chemical, but also those subjects using these products, namely, in pathology and anatomy laboratories where FA is commonly used as a fixative and tissue preservative (Costa et al., 2011).

During the last decades, cytogenetic biomarkers in peripheral blood lymphocytes have been used to assess exposure to carcinogenic or mutagenic agents in occupational settings (Hagmar et al., 2001).Numerous studies have shown that FA is genotoxic and mutagenic to mammalian cells and the primary DNA alterations induced by FA are DNA protein crosslinks (DPCs) as a primary genotoxic effect ( $\mathrm{Lu}$ et al., 2010). There are another cytogenetic biomarkers in peripheral blood lymphocytes that have been used to assess exposure to carcinogenic or mutagenic agents in occupational settings such as SCE and Mn (Ladeira et al., 2011).Micronucleus (Mn) is the most sensitive genetic endpoints for detection of FA induced genotoxicity. $\mathrm{Mn}$ in peripheral blood lymphocytes has been extensively used to evaluate the presence and extend of chromosome damage in human populations exposed to genotoxic agents (Viegas et al., 2010).

Among other genetic end points, FA efficiently induced sister chromatid exchanges (SCE). The mechanism of SCE formation is still not completely understood but it is clear that SCE frequencies increase when FA induced DNA-protein cross-links (DPX) persisted until S-phase of the cell cycle. Thus, SCE seem to be a sensitive and reliable measure of persisting DNA alterations induced by FA (Neuss $\mathrm{S}$. and Speit G., 2008).

\section{Materials and Methods}

The study was carried in the histopathology laboratory at Kasr Al-Aini Hospital, Cairo University. The studied population comprised 30 persons occupationally exposed to formaldehyde, 12 pathologists, 12 technicians and 6 workers with age ranges 22 to 55 years and a control group of 29 personels, randomly 
selected from other lab in kasr Al Aini hospital matching the exposed group for age, sex and socioeconomic status with no history of occupational exposure to formaldehyde. The exposure duration was calculated by multiplying weekly working hours in a year with years of employment.

A. Environmental monitoring was done in different places of the Histopathology laboratory using a portable Formaldemeter. The sites of monitoring covered all possible exposure areas including corridors, sites of receiving the specimen, place of microscopic examination of the specimen, trimming and preparation of the specimens for microscopic examination.

B. A self designed questionnaire was done including inquiries about age, sex, occupational history and special habits.

\section{Investigations}

1-Cytogenetic biomarkers: 4-5ml of peripheral blood sample was obtained in heparinized syringe. Lymphocytes were isolated and cytogenetically investigated by two techniques namely; Sister Chromatid Exchanges (SCEs) and Cytokinesis-block micronucleus cytome assay.

\section{1-Sister Chromatid Exchanges} (SCEs) technique (Verma and Babu, 2006).

$0.5 \mathrm{ml}$ drops of blood were added to culture tube containing $4 \mathrm{ml}$ RPMI1640 culture media, $1 \mathrm{ml}$ fetal bovine serum, $0.05 \mathrm{ml}$ penicillin, streptomycin, $0.05 \mathrm{ml} \mathrm{L}$-glutamine and $0.1 \mathrm{ml}$ of phytohemaglutinine then incubated at $37 \mathrm{oC}$ for $72 \mathrm{hrs}$. After $72 \mathrm{hrs}, 0.05 \mathrm{ml}$ of colcemid $(10 \mu \mathrm{g} / \mathrm{ml})$ was added to each culture tube and centrifuged.The cell sediment was re-suspended in 5 $\mathrm{ml}$ of $0.56 \%$ Potassium Chloride and incubated for $30 \mathrm{~min}$ at $37 \mathrm{oC}$. After final centrifugation, the cells were suspended in a small volume of fixative and spread on slides. The slides were immersed in opaque jar containing 0.01 $\mathrm{g} / 50 \mathrm{ml}$ Hochest 33258 dye for $45 \mathrm{~min}$ and rinsed in distilled water and layered with Mcllvaine's buffer then stained by freshly prepared Giemsa staining solution for 1-2 minute. SCEs counting were done under the microscope and scored on in cell with 46 chromosomes. Fifty metaphases were analyzed for each case and SCEs were scored per metaphase. 
1.2-Cytokinesis-block micronucleus cytome assay (Fenech, 2007)

The technique was done as described in SCEs technique except that Cytochalasin B was added to each tube with final concentration 3-5 $\mu \mathrm{g} / \mathrm{ml}, 44 \mathrm{hrs}$ after culture initiation and no colcemid was added then the slides were stained by freshly prepared Giemsa staining solution for $1-2$ min. A total of 1000 binucleated cells with well-preserved cytoplasm were examined for each donor. The frequencies of binucleated cells with Mn were determined by analyzing 1,000 binucleate lymphocytes from two slides for each subject.

\section{3- DNA-protein crosslinks} (DPC).

DPC were assessed in isolated lymphocytes using K-SDS assay. In this method DNA fragments containing covalently attached proteins were selectively precipitated in the presence of $\mathrm{KCl} / \mathrm{SDS}$. Cells or DNA/histone mixtures were lysed in $1 \%$ SDS, cellular lysates were sheared by passing through $21 \mathrm{G}$ needles and DPC were precipitated by addition of $200 \mathrm{mM} \mathrm{KCl}$. Dependence of DNA precipitation on the presence of attached proteins was verified by elimination of $\mathrm{KCl} / \mathrm{SDS}$-precipitable DNA by pre-treatment of samples with $0.2 \mathrm{mg} / \mathrm{ml}$ proteinase $\mathrm{K}$ for $1 \mathrm{~h}$ at $37^{\circ} \mathrm{C}$ prior to crosslink analysis. $0.1 \mu \mathrm{g} / \mathrm{ml}$ of Hoechst dye 33258 was added and DPC was measured as a percent $(\%)$ in the presence of $0.5 \mu \mathrm{M}$ Hochest in a multi well fluorescence reader (Quievryn and Zhitkovich, 2000).

\section{D- Statistical analysis}

Data was coded and analyzed using the statistical package SPSS version 16 . The mean values, standard deviation (SD), median and ranges were estimated for quantitative variables, as for the qualitative variables, the frequency distribution was calculated. Comparisons between exposed and control groups were done using Chi Square $\left(\chi^{2}\right)$ test for qualitative variables and using the independent simple t-test for normally distributed quantitative variable. Analysis of variance (ANOVA) test was done between different categories of the exposed group. The non-parametrical Mann-Whitney test was used for quantitative variables not normally distributed. Correlations were done to test for the presence of linear relations between quantitative variables. P-values less than 0.05 were considered statistically significant. 


\section{Consent:}

Authors declare that a verbal consent was taken from the studied group and consent from pathology department before making the environmental study. Confidentiality was maintained.

\section{Ethical approval}

The study protocol was approved by Occupational and Environmental Department Ethical Committee, Faculty of Medicine, Cairo University.

\section{Results}

Environmental monitoring revealed that the higher level of FA was present at the site of formaldehyde disposal (mean \pm SD $2.04 \pm 1.3 \mathrm{ppm}$ ) followed by the site of tissue processor after its opening (mean \pm SD $1.81 \pm 0.76 \mathrm{ppm}$ ) where technicians are working. The lower level was observed at the site of receiving and trimming the specimen (mean \pm SD $0.66 \pm 0.21$ and $0.87 \pm$
0.24 respectively) done by pathologists followed by the site of cut section using microtone (mean \pm SD $0.42 \pm 0.02 \mathrm{ppm})$ and corridor (mean \pm SD $0.42 \pm 0.16$ ppm) where technicians and workers were present. The results obtained from the environmental study of our work were found to exceed the exposure limit recommended by NIOSH $(0.016$ ppm), OSHA Permissible Exposure Limit (OSHA PEL) (0.75ppm) for the 8-hour Time- Weighted Average (TWA) and ACGIH ceiling limit (0.3ppm) (ATSDR, 2008).

There was no significant difference in the demographic characteristics between the exposed and control groups. But there is significant statistical difference between different subgroups of the exposed as regards smoking habits being more prevalent among technicians. 
Table (1): Genotoxic parameters (DNA-protein crosslinks (DPC), MN and SCE) among exposed and control groups.

\begin{tabular}{|c|c|c|c|c|}
\hline Parameters & $\begin{array}{c}\text { Exposed } \\
\text { Group }(\mathbf{n = 3 0}) \\
\text { Mean } \pm \text { SD }\end{array}$ & $\begin{array}{c}\text { Control } \\
\text { Group }(\mathbf{n = 2 9}) \\
\text { Mean } \pm \text { SD }\end{array}$ & t test & P value \\
\hline DPC & $4.18 \pm 3.34$ & $0.70 \pm 0.27$ & 5.58 & $0.000^{* *}$ \\
\hline Mn & $24.86 \pm 13.97$ & $17.34 \pm 7.09$ & 2.59 & $0.012^{*}$ \\
\hline SCE & $10.01 \pm 2.16$ & $6.39 \pm 1.02$ & 8.14 & $0.000^{* *}$ \\
\hline
\end{tabular}

*Significant $(\mathrm{P}<0.05)$.

**Highly significant $(\mathrm{P}<0.005)$.

Table (1) showed statistically highly significant increase for genotoxic parameters (DPC, Mn and SCE) among exposed group when compared to the control group.

Table (2): Genotoxic parameters (DPC,Mn and SCE) of the exposed group according to smoking habit.

\begin{tabular}{|c|c|c|c|c|c|}
\hline \multicolumn{2}{|c|}{ Parameters } & $\begin{array}{c}\text { Smokers } \\
(\text { no=7) }\end{array}$ & $\begin{array}{c}\text { Non smokers } \\
(\text { no=23) }\end{array}$ & U test & p value \\
\hline \multirow{2}{*}{ DPC } & $\begin{array}{c}\text { Median } \\
\text { Range }\end{array}$ & $\begin{array}{c}2.70 \\
1.4-11.7\end{array}$ & $\begin{array}{c}2.90 \\
1.5-14.3\end{array}$ & 79.50 & n.s. \\
\hline \multirow{2}{*}{ Mn } & Median & 22.00 & 24.00 & & \\
& Range & $14-75$ & $3-46$ & 63.00 & n.s. \\
\hline \multirow{2}{*}{ SCE } & Median & 9.30 & 10.00 & & \\
& Range & $8-12$ & $7.5-17$ & 78.00 & n.s. \\
\hline
\end{tabular}

n.s.: Non-significant $(\mathrm{P}>0.05)$.

Table (2) showed a non-significant effect of smoking on DPC, SCE and Mn parameters ( $\mathrm{p}$ value $>0.05$ ). 
Table (3): Genotoxic (DPC, Mn and SCE) of the exposed group according to gender.

\begin{tabular}{|c|c|c|c|c|c|}
\hline \multicolumn{2}{|c|}{ Parameters } & Male (no=10) & Female (no=20) & U test & p value \\
\hline \multirow{2}{*}{ DPC } & $\begin{array}{c}\text { Median } \\
\text { Range }\end{array}$ & $\begin{array}{c}3.15 \\
1.60-11.70\end{array}$ & $\begin{array}{c}2.85 \\
1.40-14.30\end{array}$ & 87.00 & n.s. \\
\hline \multirow{2}{*}{ Mn } & $\begin{array}{c}\text { Median } \\
\text { Range }\end{array}$ & $\begin{array}{c}22.00 \\
11.00-75.00\end{array}$ & $\begin{array}{c}24.00 \\
3.00-46\end{array}$ & 99.50 & n.s. \\
\hline \multirow{2}{*}{ SCE } & $\begin{array}{c}\text { Median } \\
\text { Range }\end{array}$ & $\begin{array}{c}9.65 \\
8.00-12.00\end{array}$ & $\begin{array}{c}9.65 \\
7.50-17.00\end{array}$ & 95.50 & n.s. \\
\hline
\end{tabular}

n.s.: non-significant $(\mathrm{P}>0.05)$

Table (3) showed a non-significant effect of gender on DPC, SCE and Mn parameters ( $\mathrm{p}$ value $>0.05)$.

Table (4): Pearson correlation between age and duration of exposure with DPC, micronucleus and sister chromatide exchange among workers exposed to formaldehyde in histopathology laboratory $(n=30)$.

\begin{tabular}{|c|c|c|c|c|}
\hline \multicolumn{2}{|c|}{ Parameters } & DPC & Mn & SCE \\
\hline \multirow{2}{*}{ Age } & r value & 0.129 & 0.214 & 0.269 \\
& P value & 0.496 & 0.257 & 0.151 \\
\hline Duration of & r value & 0.014 & 0.198 & 0.321 \\
exposure & P value & 0.940 & 0.293 & 0.084 \\
\hline \multirow{2}{*}{ DPC } & r value & --- & 0.082 & 0.207 \\
& P value & --- & 0.666 & 0.272 \\
\hline
\end{tabular}

Table (4) showed the effects of age and duration of exposure on genotoxic parameters (DPC, micronucleus and sister chromatid exchange), no significant correlation was found among the exposed group $(\mathrm{P}>0.05)$. As well, no significant correlation was found between DPC, SCE and Mn. 
Table (5): Analysis of variance (ANOVA) for duration of exposure, DPC, SCE and Mn among the different categories of exposed group $(n=30)$.

\begin{tabular}{|c|c|c|c|c|c|c|}
\hline \multicolumn{2}{|c|}{ Parameters } & $\begin{array}{c}\text { Pathologists } \\
(\mathbf{n = 1 2})\end{array}$ & $\begin{array}{c}\text { Technicians } \\
(\mathbf{n = 1 2})\end{array}$ & $\begin{array}{c}\text { Workers } \\
(\mathbf{n = 6})\end{array}$ & f test & P value \\
\hline $\begin{array}{c}\text { Duration } \\
\text { of } \\
\text { exposure }\end{array}$ & $\begin{array}{c}\text { Median } \\
\text { Range }\end{array}$ & $\begin{array}{c}2340 \\
1040-3120\end{array}$ & $\begin{array}{c}7150 \\
2600-28600\end{array}$ & $\begin{array}{c}31200 \\
7488-49920\end{array}$ & 10.08 & $0.000 * *$ \\
\hline DPC & $\begin{array}{c}\text { Median } \\
\text { Range }\end{array}$ & $\begin{array}{c}2.65 \\
1.50-14.30\end{array}$ & $\begin{array}{c}3.20 \\
1.50-12.70\end{array}$ & $\begin{array}{c}3.20 \\
1.40-11.70\end{array}$ & 10.22 & n.s. \\
\hline SCE & $\begin{array}{c}\text { Median } \\
\text { Range }\end{array}$ & $\begin{array}{c}10.00 \\
8.70-17.00\end{array}$ & $\begin{array}{c}10.00 \\
7.50-12.00\end{array}$ & $\begin{array}{c}8.20 \\
8.00-9.30\end{array}$ & 31.09 & $0.025 *$ \\
\hline Mn & $\begin{array}{c}\text { Median } \\
\text { Range }\end{array}$ & $\begin{array}{c}24.50 \\
14.00-30.00\end{array}$ & $\begin{array}{c}27.50 \\
10.00-75.00\end{array}$ & $\begin{array}{c}19.00-22.00 \\
\text { Mng }\end{array}$ & 5.20 & n.s. \\
\hline
\end{tabular}

*Significant $(\mathrm{P}<0.05)$. $\quad$ n.s.: non-significant $\quad * *$ Highly significant $(\mathrm{P}<0.005)$.

Table (5) showed analysis of variance (ANOVA) for duration of exposure, DPC, SCE and $\mathrm{Mn}$ among the different categories of exposed group, significant differences was found between them as regard duration of exposure and SCE.

\section{Discussion}

Many people are exposed to formaldehyde environmentally and/ or occupationally and the highest level of human exposure to FA occurs in occupational settings. In the present study, the results of environmental monitoring revealed that the higher measurements were obtained at the site of formaldehyde disposal, followed by the site of tissue processor after its opening where technicians are working. The lowest levels were observed at the site of receiving and trimming the specimen done by pathologists followed by the site of cut section using microtone and corridor where technicians and workers were present. This is in agreement with the results obtained from the study done by Costa et al. (2011) in 5 hospital pathology laboratories who found that the main FA vapor emissions occurred during the macroscopic examination of FA-preserved specimens and during the disposal of specimens and waste solutions with formaldehyde levels ranging from $0.04-1.58 \mathrm{ppm}$.

As regard the frequency distribution of personal characteristics, no significant differences were found 
between the exposed and control groups as regard age, gender and smoking habits but significant difference was found between different categories of the exposed group concerning smoking habits being more among technicians. Also a significant difference was found between them as regards exposure duration being more among workers followed by technicians and pathologists.

FA is genotoxic and mutagenic to mammalian cells and the primary DNA alterations induced by FA are DNA protein crosslinks (DPCs) as a primary genotoxic effect (Lu et al., 2010). Our results showed highly significant increase of DPC among exposed persons to formaldehyde compared to the controls. Similar results were found by Shaham et al., (2003) who concluded that exposure to formaldehyde causes the formation of DPC in human peripheral white blood lymphocytes and that assay is sensitive enough to discriminate between exposed and unexposed workers. As well Sameer and his colleagues (2012) found an increased level of DNA damage in peripheral blood lymphocytes of medical staff exposed to formaldehyde and this DNA damage originate from DNA single-strand breaks, repair of DNA double-strand breaks, DNA adduct formation or DNA-DNA and DNA-protein cross links.

In addition to DPC, there are other cytogenetic biomarkers in peripheral blood lymphocytes that have been used to assess exposure to carcinogenic or mutagenic agents in occupational settings such as sister chromatide exchanges (SCE) and micronucleus frequencies $(\mathrm{Mn})$. Our study showed significant increase of genotoxic biomarkers (SCE and Mn) among the exposed group when compared to the control group with significant more increase of these biomarkers among technicians and pathologists than among workers. This may be explained by their presence at areas with formaldehyde levels higher than areas where workers are present since the study done by Costa et al., (2008) mentioned that Mn frequencies will increase with increasing levels of formaldehyde. Our results agreed with the results of Ladeira et al., (2011), Ye et al., (2005) and Shaham et al., (2002) who compared the frequency of genotoxicity biomarkers between individuals occupationally exposed 
and non-exposed to formaldehyde and found that significant increases in DPC, SCE and Mn frequencies among exposed workers in comparison with the control but this disagreed with the results of Saad et al., (2006) who found no significant differences in SCE among exposed workers compared to their control.

Concerning the influence of age and gender on Mn frequency, no significant correlations were found between age and $\mathrm{Mn}$ frequency. As for gender no significant differences in $\mathrm{Mn}$ frequencies were found between males and females. This is against Viegas et al., (2010) who mentioned that $\mathrm{Mn}$ frequencies tend to rise with age because of the progressive increase in spontaneous chromosomal instability and the loss of efficiency in DNA repair mechanisms resulting in accumulation of genetic lesions with increasing age and also against Wojda et al., (2007) results who found significant increase in $\mathrm{MN}$ frequencies in women.

Tobacco smoke contains a high number of mutagenic and carcinogenic substances and is causally linked to an elevated incidence of several forms of cancers. Hence, smoking is an important variable to consider in biomonitoring studies and particularly in this study since FA is present in tobacco smoke. The effect of tobacco smoking on SCE and $\mathrm{Mn}$ frequency in human cells has been object of study. Our study showed no significant difference in SCE and $\mathrm{Mn}$ frequency between smokers and non-smokers and no effects of smoking on DPC, P53. This is similar to Viegas et al., (2010) who found no significant difference in $\mathrm{MN}$ frequency (in peripheral blood lymphocytes and epithelial buccal cells) between smokers and non-smokers.

As genotoxicity are considered to play important roles in the carcinogenesis of FA (IARC 2006), the genotoxic effects of formaldehyde in peripheral blood lymphocytes and the association of these cytogenetic effects with formaldehyde exposure gives important information to risk assessment process and may also be used to assess health risks for exposed workers (Viegas et al., 2010).

Conclusion and Recommendations: The studied group was exposed to formaldehyde level above the exposure limits recommended by NIOSH,ACGIH and OSHA with adverse health effects in the form of increase in DPC, SCE 
and $\mathrm{Mn}$ as genotoxicity biomarkers. These genotoxicity biomarkers are considered to play an important role in the carcinogenesis of FA. So we recommend regular environmental monitoring not to exceed exposure permissible limits, establishment and use of engineering control, regular health education and training with auditing of safe work practices and use of personal protective equipments. I

\section{Competing interests}

Authors have declared that no competing interests exist.

\section{References}

1. Agency for Toxic Substances and Disease Registry (ATSDR) (2008): Medical management guidelines for formaldehyde. Department of health and human services. Atlanta, Georgia, USA.

2. Conrad S, Künzel J, and Löbrich M (2011): Sister chromatid exchanges occur in G2irradiated cells Cell Cycle; 10(2): 222-8.

3. Costa S, Pinaa C, Coelhoab P, Costa C, Silvaa S, Portoc B, Laffond B and Paulo J(2011):Occupational exposure to formaldehyde: genotoxic risk evaluation by comet assay and micronucleus test using human peripheral lymphocytes. J Tox Env Health; 74 (15-16): 1040-51.

4. Fenech M (2007): Cytokinesis-block micronucleus cytome assay. Nature Protocols; 2(5):1084.

5. Hagmar L, Strömberg U, Tinnerberg $\mathrm{H}$ and Mikoczy Z (2001): The usefulness of cytogenetic biomarkers as intermediate endpoints in carcinogenesis. Int $\mathbf{J}$ Hyg Env Health ; Oct; 204(1):43-7.

6. International Agency for Research on Cancer (IARC) (2006): Formaldehyde, 2-butoxyethanol, and 1-tert-butoxy-2propanol. Monogr Eval Carcinog Risks Hum; Vol 88.

7. Ladeira C, Viegas S, Carolino E, Prista J, Gomes M and Brito M (2011): Genotoxicity biomarkers in occupational exposure to formaldehyde-the case of histopathology laboratories. Mutat Res; 721(1):15-20.

8. Lu K, Ye W, Zhou L, Leonard B, Chen X, Gold A, Louise M and James A (2010): Structural Characterization of Formaldehyde-Induced Cross-Links Between Amino Acids and Deoxynucleosides and Their Oligomers. J Am Chem Soc; 132 (10): 3388-99.

9. Mueller JU, Bruckner T and Triebig G (2013): Exposure study to examine chemosensory effects of formaldehyde on hyposensitive and hypersensitive males. Int Arch Occup Env Health; 86 (1): 107-17.

10. Neuss S and Speit G (2008): Further characterization of the genotoxicity of formaldehyde in vitro by the sister chromatid exchange test and co-cultivation experiments. Mutagenesis; 23(5): 355-7.

11. Quievryn G and Zhitkovich A (2000): Loss of DNA-protein crosslinks from formaldehydeexposed cells occurs through spontaneous hydrolysis and an active repair process linked to proteosome function. Carcinogenesis; 21(8): 1573-80.

12. Saad A, Beshir S and Baathallah S (2006): Prediction of Respiratory Hazards, Cytotoxicity, and Carcinogenicity of Occupational Exposure to Formaldehyde in Pathology Laboratories. JASMR; 1 (1).

13. Sameer MG, Elmesallamy GE and Mohamad MS (2012): Evaluation of genotoxic effects of formaldehyde in adult albino rats and its 
implication in case of human exposure. Life Sci J; 9(4): 3085 - 93.

14. Shaham J, Gurvich R and Kaufman Z (2002): Sister chromatid exchange in pathology staff occupationally exposed to formaldehyde. Mutat Res ; 514(1-2):115-23.

15. Shaham J, Bomstein Y, Gurvich R, Rashkovsky $M$ and Kaufman Z (2003): DNA-protein crosslinks and p53 protein expression in relation to occupational exposure to formaldehyde. Occup Env Med; 60:403-409.

16. Sirbu BM, Lachmayer SJ, Wülfing V et al. (2011): ATR-p53 restricts homologous recombination in response to replicative stress but does not limit DNA inter strand crosslink repair in lung cancer cells. PLoS One ; 6(8):e23053.

17. Speit G and Schmid O (2006): Local genotoxic effects of formaldehyde in humans measured by the micronucleus test with exfoliated cells. Mutat Res; 613(1):1-9.
18. Verma RS and Babu A (2006): Human chromosomes, Manual of Basic Techniques. McGraw Hill, (2nd Ed), NewYork, Pergamon Press, 2006.

19. Viegas S, Nunes C, Malta-Vacas J, Gomes M, Brito M, Mendonça P and Prista J (2010): Genotoxic effects in occupational exposure to formaldehyde: A study in anatomy and pathology laboratories and formaldehyde-resins production. J Occup Med Toxicol; 5(1): 5-25.

20. Wojda A, Zietkiewicz E and Witt M (2007): Effects of age and gender on micronucleus and chromosome non disjunction frequencies in centenarians and younger subjects. Mutagenesis; 22(3): 195-200.

21. Ye X, Yan W, Xie H, Zhao $M$ and Ying $C$ (2005): Cytogenetic analysis of nasal mucosa cells and lymphocytes from high-level longterm formaldehyde exposed workers and low level short-term exposed waiters. Mutat Res; 588(1):22-7. 